\title{
$\mathfrak{g n}$ Aflemoriam
}

\section{CARLOS EDUARDO CASTAÑEDA}

$1896-1958$

$\mathrm{O}$

$\mathrm{N}$ April 5 we at the Academy of American Franciscan History received the sad news of the death of Dr. Carlos E. Castañeda. He had been ailing for some years, but recently had become more active again, so that his friends hoped for many more years of life for him. The Master of life and death thought differently.

"Don Carlos," as his friends called him, had a full life. Born in Camargo, Mexico, on November 11, 1896, he came to the United States in 1908 and became a citizen of the United States. After completing his high school studies in Brownsville, Texas, he entered the University of Texas and obtained the degree of Bachelor of Arts in 1921, Master of Arts in 1923, and Doctor of Philosophy in 1932.

After high school he began studies in engineering, and spent a year in field work near Tampico. That one year was enough to convince him that he was not cut out to be an engineer. Besides, his interest in Southwestern history had been stimulated by a class under Dr. Charles W. Hackett, and this was to be his life's work.

Dr. Castañeda was uniquely qualified for work in the field of the history of Texas and Mexico because of his background of languages and culture. His first historical article was published in 1921, and appropriately enough, it was concerning early missionary activity in Texas. From that time to the present he published an amazing amount of books, articles, and pamphlets, of which we will mention here only the principal works. A complete list of his writings was published in THE AMERICAS, Vol. VIII, No. 4 (April, 1952): it covers eight pages (485-492).

His first teaching appointment was at William and Mary College in Williamsburg, Virginia, where he taught Spanish and Spanish American Literature. In 1927 he returned to the University of Texas, and was made librarian of the Genaro García Collection, which certainly whetted his appetite for things Spanish American.

While gathering material for his dissertation in Mexico Dr. Castañeda had the good fortune to find among the manuscripts of the National 
Library the "lost" history of Texas by the Franciscan missionary, Fray Juan Agustín Morfi, which he published in a critical edition as his doctoral thesis. The Quivira Society then published the work in two large volumes (Albuquerque, 1935).

The fame that came to Dr. Castañeda because of this edition of Morfi led directly to the magnum opus of his life: a complete and authoritative history of Texas inappropriately named Our Catbolic Heritage in Texas, 1519-1936 (6 vols.; Austin, 1936-1950).

During the years he was laboring on this narrative history, Dr. Castaneda continued to teach at the University of Texas, becoming full professor in 1946. He was honored by many cultural institutions in this country and abroad. In 1939-1940 he was president of the American Catholic Historical Association. He was also an advisory editor of the Hispanic American Historical Review, and of this magazine.

I know of no better way to bring this homage to a close than to quote the words of the Director of the Academy of American History, Fr. Alexander Wyse, O. F. M., when he conferred upon Dr. Castañeda the "Serra Award of the Americas" in 1951:

Gifted by nature with an admirable diligence and industry, accompanied by good fortune in his painstaking search for the fragments of the past, bringing to the interpretation of history a sound scholarship coupled with an impartial devotion to Truth, Carlos Eduardo Castañeda occupies a place of eminence among American historians. His publications, marked alike by an engaging originality and an unquestionable profundity, have enriched forever the cultural life of our nation and reach out, like a mighty ocean of good-will, to embrace the whole expanse of the Americas. In his noble profession of educator he has had the quality of inspiring his students, and they, enkindled by the fire of his enthusiasm, form a generation of young scholars whose growing reputations in various Universities of the country reflect vicarious glory on the master himself. His public and private virtues as a broad-visioned and self-sacrificing citizen, a devoted father of a Christian family, a dedicated communicant and faithful son of the Catholic Church, shower further distinction on a career already notable for scholarly attainments.

... Wherefore ... the Academy of American Franciscan History confers the Serra Award of The Americas for 1951 upon Carlos Eduardo Castañeda, author, educator, historian, in recognition of his spiritual and cultural contributions toward promoting Inter-American good-will and in tribute to his monumental researches in the history of Texas and the Southwest.

R.I.P.

Mathias C. Kiemen, O. F. M. 